ISSN 0103-8478

\title{
Silages of pearl millet submitted to nitrogen fertilization
}

\author{
Silagens de milheto submetidas à adubação nitrogenada
}

\author{
Ricardo Martins Araujo Pinho ${ }^{I^{*}}$ Edson Mauro Santos ${ }^{\mathrm{I}}$ Fleming Sena Campos ${ }^{\mathrm{II}}$ \\ João Paulo de Farias Ramos ${ }^{\mathrm{I}}$ Carlos Henrique Oliveira Macedo ${ }^{\mathrm{I}}$ \\ Higor Fábio Carvalho Bezerra ${ }^{\mathrm{I}}$ Alexandre Fernandes Perazzo ${ }^{\mathrm{II}}$
}

\section{ABSTRACT}

This study aimed to evaluate the fermentation characteristics, losses and the chemical composition of two pearl millet genotypes silages submitted to nitrogen fertilization. The experimental design was a completely randomized blocks in a split plot scheme $2 \times 5$ (two nitrogen genotypes doses $x$ five doses of nitrogen), with four replicates. Nitrogen doses were 0, 20, 40,60, $80 \mathrm{~kg} \mathrm{ha}^{-1}$ and the pearl millet genotypes were the variety ADR300 and the hybrid ADR7010. The hybrid ADR 7010 showed average lactic acid content higher than the variety $A D R 300$, at all doses of $N$, recording values ranging from 4.09 to $10.46 \mathrm{dag} \mathrm{kg}^{-1}$. There was an interaction between nitrogren doses and genotypes for the neutral detergent fiber, which ranged from 51.81 to 63.63dag $\mathrm{kg}^{-1}$ of dry matter. Dry matter recovery decreased linearly with increasing nitrogen doses only for hybrid ADR7010, the same did not happen for the ADR300. The nitrogen fertilization does not favor the fermentation characteristics and increases DM losses of the hybrid ADR7010.

Key words: chemical composition, fermentation characteristics, lactic acid, semi-arid.

\section{RESUMO}

Objetivou-se avaliar o perfil fermentativo, as perdas e a composição bromatológica de silagens de dois genótipos de milheto, submetidos à adubação nitrogenada. $O$ delineamento utilizado foi em blocos casualizados em um esquema de parcelas subdivididas $2 \times 5$ (dois genótipos $x$ cinco doses de nitrogênio), com quatro repetições. As doses de nitrogênio foram 0, 20, 40, 60, $80 \mathrm{~kg} \mathrm{ha}^{-1}$ e os genótipos de milheto foram a variedade ADR300 e o híbrido ADR7010. O híbrido ADR 7010 apresentou teores médios de ácido lático superiores aos da variedade ADR $300 \mathrm{em}$ todos os níveis de $N$, registrando valores que variaram de 4,09 a 10,46 dag $\mathrm{kg}^{-1}$. Houve interação entre os níveis de adubo e os genótipos para a fibra em detergente neutro, que variaram de 51,81 a 63,63dag $\mathrm{kg}^{-1}$ de matéria seca. A recuperação de matéria seca diminuiu linearmente com o aumento das doses de nitrogênio somente para o híbrido ADR7010, o mesmo não acontecendo para a ADR300. A adubação nitrogenada não favorece o perfil fermentativo $e$ incrementa as perdas de matéria seca do híbrido ADR7010.

Palavras-chave: composição bromatológica, perfil fermentativo, ácido lático, semiárido.

\section{INTRODUCTION}

The pearl millet is grass specie has been widely used by farmers as an alternative to reach the animal requirements in the critical period of the year, due to the fact that it is the forage more resistant to drought and is adapted to low soil fertility, presents fast growth and high yields of phytomass by unit area (AMARAL et al., 2008). It is a culture that shows good development in regions with low rainfall profile, so, it has been widely used for the production of grass silage during periods of late season and in regions that are characterized by having problems with dry periods or drought (GUIMARÃES JR. et al., 2010).

The nitrogen is considered one of the most important nutrients for the growth of several plant species because it can provide an increase in productivity of forage grass and in the amount of crude protein (CP) per hectare. But the responses to nitrogen depend on each forage species, being attributed to genetic constitution, soil and climatic conditions (DIAS et al., 2000).

\footnotetext{
${ }^{1}$ Universidade Federal da Paraíba (UFPB), 58397-000, Areia, PB, Brasil. E-mail: ricardo-zootec@hotmail.com. *Autor para correspondência.

"Universidade Federal da Bahia (UFBA), Salvador, BA, Brasil. 
The efficiency of the silage conservation system should not be defined only by the nutritional value of silage, but also by the losses that occur from harvest to animals feeding (NEUMANN et al., 2007). The silage quality is directly related to the material which it is originated from and to the conditions under which it was ensiled (LOURES et al., 2003). In this way, changes occurring owing fertilization can provide changes in silage quality.

Therefore, this study aimed to evaluate the fermentation characteristics and the chemical composition, as well as to quantify the losses and dry matter recovery of two pearl millet genotypes silage submitted to nitrogen fertilization.

\section{MATERIALS AND METHODS}

The experiment was conducted at the Estação Experimental Pendência, of Empresa Estadual de Pesquisa Agropecuária da Paraíba S.A. (EMEPA), located in Agreste region of Paraiba, Microregion of Western Curimataú, municipality of Soledade. The precipitation volume during the experimental period (May to July 2010) was $96 \mathrm{~mm}$.

The soil analysis of the experimental area was conducted in the laboratory of Federal University of Paraiba, presenting the following chemical attributes (profiles 0 to $20 \mathrm{~cm}): \mathrm{pH}\left(\mathrm{H}_{2} \mathrm{O}\right): 6,32 ; \mathrm{P}: 1,63 ; \mathrm{K}^{+}: 159$ $\left(\mathrm{mg} \mathrm{dm}{ }^{3-1}\right) ; \mathrm{H}^{+}+\mathrm{Al}^{+3}: 1,49 ; \mathrm{Al}^{+3}: 0,0 ; \mathrm{Ca}^{+2}: 5,85 ; \mathrm{Mg}^{+2}$ : $1,10\left(\mathrm{cmol}_{\mathrm{c}} \mathrm{dm}^{3-1}\right)$, base saturation $(\mathrm{V}): 83.87 \mathrm{dag}_{\mathrm{kg}^{-1}}$ and organic matter (OM): $8.60 \mathrm{~g} \mathrm{~kg}^{-1}$.

At the stage of pearl millet cultivation, it was used split-plot design with them hole plots arranged in a randomized complete-block design, with the plots represented by the dosages of nitrogen $\left(0,20,40,60,80 \mathrm{~kg} \mathrm{ha}^{-1}\right)$, and the subplots represented by pearl millet genotypes (variety ADR300 and hybrid ADR7010), with four replications. The spacing used in the culture was $0.5 \mathrm{~m}$ between rows. The sowing of millet was held on May 4, 2010. At 15 days after emergence (DAE) it was performed the thinning, to obtain 15 plants/linear meter.

The nitrogen fertilization with ammonium sulfate $\left(\left(\mathrm{NH}_{4}\right)_{2} \mathrm{SO}_{4}\right)$ was performed, manually, directly beside the rows of plants, being the dosages of 20 and $40 \mathrm{~kg} \mathrm{ha}^{-1}$ applied once, at 14 days after sowing (DAS), and the remaining dosages in installments, half of them applied at 14 days and half at 28DAS. At the time of sowing, it was performed the phosphate fertilization with $50 \mathrm{~kg} \mathrm{ha}^{-1}$ of $\mathrm{P}_{2} \mathrm{O}_{5}$, using simple superphosphate.

In this experiment, which corresponds to the evaluation of the silages, all the material for each combination of the factors studied in the four blocks was cut for ensilage, and replicates were established by experimental silos. Thus, the experimental design was completely randomized in a $2 \times 5$ factorial scheme, with two pearl millet genotypes (variety ADR300 and the hybrid ADR7010) and five nitrogen dosages ( 0 , $20,40,60$ and $80 \mathrm{~kg} \mathrm{ha}^{-1}$ ) with four replicates.

The harvest of plants was done 64DAS, when the grains were in early-dough stage. In the plots of each treatment, the millet was cut to a height of $10 \mathrm{~cm}$ from the ground and chopped into particles of approximately $2 \mathrm{~cm}$ and ensiled in PVC silos with $15 \mathrm{~cm}$ diameter and $30 \mathrm{~cm}$ height, equipped with Bunsen valve, to exhaust gases. At the bottom of the silos, it was placed $1.50 \mathrm{~kg}$ of sand to capture the effluent. The compaction of the material allowed approximately $3 \mathrm{~kg}$ of fresh forage per silo. The usable area of silo was $15 \mathrm{~cm}$ diameter and $28 \mathrm{~cm}$ height.

After 30 days, the silos were opened, and then it was collected two samples of each experimental unit, in order to perform the analysis at the Laboratory of Animal Nutrition of the Center of Agrarian Sciences at the Federal University of Paraiba (UFPB).

At opening time, it was eliminated the top and bottom portions of each one, equivalent to approximately $5 \mathrm{~cm}$ each. The central portion was homogenized and a sample of approximately $200 \mathrm{~g}$ for the determination of $\mathrm{pH}$ and ammonia nitrogen was used. The analysis of $\mathrm{pH}$ and ammonia-N were conducted according to the methodology described by BOLSEN et al. (1992). For analysis of organic acids, $10 \mathrm{~g}$ of sample was diluted in $90 \mathrm{~mL}$ of distilled water and filtered through Whatman filter (KUNG JR. \& RANJIT, 2001).

Also at the opening moment, another sample of approximately $200 \mathrm{~g}$ was collected from each silo. These samples were pre-oven-dried at $65^{\circ} \mathrm{C}$ for $72 \mathrm{~h}$ and ground in a Willey knife mill with a $1 \mathrm{~mm}$ sieve for determination of the chemical constituents.

Measurements of dry matter (DM), ether extract (EE), and crude protein (CP) was determined by using the methods described by SILVA \& QUEIROZ (2002). The content of neutral detergent fiber (NDF) was evaluated according MERTENS (2002), using an Ankom fiber analyzer. In the NDF, the samples were treated with alpha-amylase heat-stable without the use of sodium sulfite. The determination of soluble carbohydrates (SC) was performed according to DERIAZ (1961). It was calculated the concentration of total carbohydrates and of the non-fibrous carbohydrates, according to SNIFFEN et al. (1992). The main values of the chemical composition of the genotypes before ensiling can be observed in table 1 . 
Table 1 - Average values of chemical composition of plant genotypes used for ensilage.

\begin{tabular}{|c|c|c|c|c|c|c|c|}
\hline Genotype & $\begin{array}{l}\mathrm{N} \text { doses } \\
\left(\mathrm{kg} \cdot \mathrm{ha}^{-1}\right)\end{array}$ & DM & $\mathrm{CP}$ & $\begin{array}{l}\text { NDF } \\
\text { da }\end{array}$ & $\mathrm{EE}$ & $\mathrm{NFC}$ & $\mathrm{SC}$ \\
\hline \multirow{5}{*}{ ADR 300} & 0 & 24.74 & 6.80 & 57.49 & 2.56 & 25.57 & 13.26 \\
\hline & 20 & 21.64 & 7.70 & 62.80 & 2.63 & 17.54 & 11.76 \\
\hline & 40 & 20.53 & 7.28 & 63.89 & 2.61 & 16.43 & 14.17 \\
\hline & 60 & 19.94 & 8.69 & 61.81 & 2.55 & 17.91 & 11.31 \\
\hline & 80 & 21.36 & 5.85 & 60.31 & 2.56 & 22.47 & 14.07 \\
\hline \multirow{5}{*}{ ADR 7010} & 0 & 22.27 & 6.08 & 57.36 & 2.55 & 24.56 & 11.67 \\
\hline & 20 & 19.38 & 6.76 & 56.63 & 2.60 & 25.82 & 13.39 \\
\hline & 40 & 22.35 & 6.13 & 58.21 & 2.59 & 24.61 & 15.67 \\
\hline & 60 & 22.74 & 6.12 & 52.30 & 2.55 & 29.54 & 17.17 \\
\hline & 80 & 22.45 & 6.13 & 56.60 & 2.56 & 25.33 & 18,31 \\
\hline
\end{tabular}

(DM): dry matter, (CP): crude protein, (NDF): neutral detergent fiber, (EE): ether extract, (NFC): non-fiber carbohydrates, (SC): soluble carbohydrates.

The losses of dry matter (DM) in form of gas and effluent, and the dry matter recovery (DMR) were estimated according to the equations described by ZANINE et al. (2010).

The results were submitted to analysis of variance, using the $F$ test $(\alpha=0.05)$ to compare the means between genotypes, using the program SAEG, version 8.0 (UNIVERSIDADE FEDERAL DE VIÇOSA, 2000). When there was interaction, data were unfolded to evaluate effect of genotypes in each nitrogen doses and effect of doses in each genotype. For the effect of fertilizer, it was performed linear regression analysis. The criteria for selecting the models were the coefficients of determination, as well as the significance of the regression parameters tested by Student's $t$ test $(\alpha=0.05)$.

\section{RESULTS AND DISCUSSION}

There was difference for the value of DM $(\mathrm{P}<0.05)$ between the genotypes. The variety ADR 300 presented higher value of DM than the hybrid ADR 7010 (Table 2). The values for DM decreased quadratically $(\mathrm{P}<0.05)$ with the increasing of nitrogen doses. Concerning the values of $\mathrm{CP}$ and $\mathrm{EE}$, there were not found difference $(\mathrm{P}>0.05)$ among the genotypes studied.

There was an interaction $(\mathrm{P}<0.05)$ between doses of fertilizer and genotypes for the NDF (Table 3). The NDF content increased linearly with the increasing of nitrogen dosages to the variety ADR 300 and decreased linearly to the hybrid ADR 7010. The values found are lower than those noticed by AMARAL et al. (2008) and GUIMARÃES JR. et al. (2008) wich studied cultivars of millet, and found values of NDF ranging from 60.15 to 68.63 and 70.50 and $71.2 \mathrm{dag} \mathrm{kg}^{-1} \mathrm{DM}$, respectively. The low values of NDF observed in this study may be due to drought stress suffered by the culture, due to low rainfall observed during the experimental period. This stress undergone by plant caused to accelerate its cycle, staying with a smaller size, i.e., producing a smaller amount of fibers, because there was not a further expansion of the stem, resulting in greater panicle's participation in DM.

There was an interaction $(\mathrm{P}<0.05)$ between doses of fertilizer and genotypes for the content of NFC. NFC values decreased linearly with increased dosages of nitrogen to the variety, the opposite happening for hybrid in which the values increased linearly with the increasing of nitrogen. The hybrid ADR 7010, when not fertilized, had lower amount of nonfibrous carbohydrates when compared to others. This can be explained by NDF values reported in the same table. The amount of NDF is inversely proportional to the value of NFC and, as the NDF values in the hybrid ADR 7010 decreased with the increasing in the doses of nitrogen.

There was an interaction $(\mathrm{P}<0.05)$ between the nitrogen $(\mathrm{N})$ doses and the genotypes for $\mathrm{pH}$, noting that the values differ only statistically $(\mathrm{P}<0.05)$ in the dosages of 60 and $80 \mathrm{~kg} \mathrm{ha}^{-1}$ of $\mathrm{N}$ (Table 4). Due to drought stress occurred during the experimental period, the millet shortened its cycle, so, there was not enough time for the plants extend their stems and, because of this, plants presented a small height (average height of $115 \mathrm{~cm}$ ). When 
Table 2 - Average values of dry matter (DM), crude protein (CP) and ether extract (EE) of two pearl millet genotypes silages under nitrogen $(\mathrm{N})$ fertilization.

\begin{tabular}{lclc}
\hline Genotype & $\mathrm{DM}^{1}$ & $\mathrm{CP}^{2}$ & $\mathrm{EE}$ \\
& $\mathrm{dag} \mathrm{kg}{ }^{-1} \mathrm{NM}$ & $------\mathrm{dag} \mathrm{kg}^{-1}$ & $\mathrm{DM}$------ \\
\hline ADR 300 & $18.05 \mathrm{a}$ & $8.34 \mathrm{a}$ & $1.69 \mathrm{a}$ \\
ADR 7010 & $16.23 \mathrm{~b}$ & $7.69 \mathrm{a}$ & $1.68 \mathrm{a}$ \\
Mean & 17.14 & 8.02 & 1.69 \\
N doses $\left(\mathrm{kg} \mathrm{ha}^{-1}\right)$ & & & \\
0 & 18.90 & 6.57 & 1.58 \\
20 & 17.88 & 7.55 & 1.69 \\
40 & 17.24 & 8.18 & 1.77 \\
60 & 15.24 & 9.08 & 1.63 \\
80 & 16.56 & 8.70 & 1.78 \\
Mean & 17.15 & 8.02 & 1.69 \\
$\mathrm{CV}^{3}(\%)$ & 23.42 & 34.90 & 7.42 \\
\hline
\end{tabular}

Means followed by different letters in the column differ among themselves by $\mathrm{F}$ test $(\alpha=0.05)$;

${ }^{1} \hat{\mathrm{Y}}=19,1391-0,0825 \mathrm{x}+0,0055 \mathrm{x}^{2}$

${ }^{2} \hat{Y}=6,5153+0,0639 x-0,0004 x^{2}$

${ }^{3} \mathrm{CV}-$ Coefficient of variation.

subjected to higher dosages of N, plant did not grow, hence it responded by concentrating its amount of soluble carbohydrates. It is likely that, in this case, the excess of sugar has caused a reduction in the $\mathrm{pH}$ range for growth of some species of yeast, below the ideal range recommended by McDONALD et al. (1991), between 3.8 and 4.2, which justifies the increase in losses by gasses.
There was an interaction $(\mathrm{P}<0.05)$ between $\mathrm{N}$ doses and the genotypes for the content of lactic acid (LA) (Table 4). The hybrid ADR 7010 had average contents of LA superior to the ones of the variety ADR 300, at all doses of $\mathrm{N}$, being not differed statistically $(\mathrm{P}<0.05)$, only in the absence of fertilization. The hybrid showed higher average content of LA $(\mathrm{P}<0.05)$, probably because it had a greater concentration of soluble carbohydrates, the main substrate used for fermentation of the bacteria which produce LA. According to McDONALD et al. (1991), content of 5.0 from $10.0 \mathrm{dag} \mathrm{kg}^{-1}$ of LA shows silage with an adequate fermentation patterns associated.

As for the acetic acid (AA), it was observed an interaction $(\mathrm{P}<0.05)$ between the genotypes and doses of N (Table 4$)$. Genotypes differed $(\mathrm{P}<0.05)$ only in treatment which did not receive nitrogen fertilizer. The values of AA are lower than those found by GUIMARÃES JR. et al. (2005), who reported mean values of AA of $1.04 \mathrm{dag} \mathrm{kg}^{-1} \mathrm{DM}$ for millet silages opened at 28 days after ensiling. Low concentrations of AA as seen in table 4, show that there was little incidence of fermentation by enterobacteria, which produce such acid.

Concerning the $\mathrm{N}_{-} \mathrm{NH}_{3}$, there was interaction $(\mathrm{P}<0.05)$ between genotypes and $\mathrm{N}$ dosages (Table 4). The means were different $(\mathrm{P}<0.05)$ only for the first two $\mathrm{N}$ doses $\left(20\right.$ and $\left.40 \mathrm{~kg} \mathrm{ha}^{-1}\right)$. The $\mathrm{N}_{-} \mathrm{NH}_{3}$ values are lower than those found by GUIMARẪES JR. et al. (2005), who found results ranging from 7.27 to $7.7 \mathrm{dag} \mathrm{kg}^{-1} \mathrm{NT}$. The low production of $\mathrm{N}^{-\mathrm{NH}_{3}}$ can be explained by the rapid drop in $\mathrm{pH}$, which leads to decrease in populations

Table 3 - Average values of neutral detergent fiber (NDF) and non-fiber carbohydrates (NFC) in dagkg ${ }^{-1} \mathrm{DM}$ of two pearl millet genotypes silages under nitrogen $(\mathrm{N})$ fertilization.

\begin{tabular}{|c|c|c|c|c|c|c|c|}
\hline \multirow{2}{*}{ Genotype } & \multicolumn{7}{|c|}{ } \\
\hline & 0 & 20 & 40 & 60 & 80 & & \\
\hline & \multicolumn{7}{|c|}{ 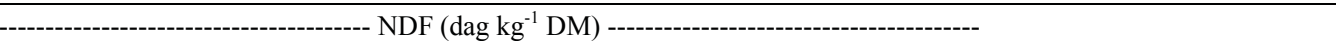 } \\
\hline ADR $300^{1}$ & $52.67 \mathrm{~b}$ & $56.10 \mathrm{~b}$ & $57.62 \mathrm{a}$ & $59.98 \mathrm{a}$ & $60.20 \mathrm{a}$ & 57.31 & 10.12 \\
\hline \multirow[t]{2}{*}{ ADR $7010^{2}$} & $63.63 \mathrm{a}$ & $60.91 \mathrm{a}$ & $57.60 \mathrm{a}$ & $53.82 \mathrm{~b}$ & $51.81 \mathrm{~b}$ & 57.55 & 10.12 \\
\hline & & & (dag kg & ---- & --- & & \\
\hline $\operatorname{ADR} 300^{3}$ & $29.65 a$ & $24.61 \mathrm{a}$ & $22.90 \mathrm{a}$ & $19.50 \mathrm{a}$ & $20.19 \mathrm{a}$ & 22.90 & 10.12 \\
\hline ADR $7010^{4}$ & $19.78 b$ & $21.26 \mathrm{a}$ & $24.49 \mathrm{a}$ & $25.65 a$ & $26.50 \mathrm{a}$ & 24.49 & 10,12 \\
\hline
\end{tabular}

Means followed by same letter in column do not differ by $\mathrm{F}$ test $(\alpha=0.05)$.

${ }^{1} \hat{Y}=53,5770+0,0932 x \quad r^{2}=0,90$

${ }^{2} \hat{Y}=61,6815-0,1536 x \quad r^{2}=0,83 ;$

${ }^{3} \hat{Y}=28,1750-0,12 x \quad r^{2}=0,87$

${ }^{4} \hat{Y}=19,3955+0,0905 x \quad r^{2}=0,91 ;$

${ }^{5} \mathrm{CV}-$ Coefficient of variation. 
Table 4 - Mean values of fermentation profile in silages of two pearl millet genotypes under nitrogen $(\mathrm{N})$ fertilization

\begin{tabular}{|c|c|c|c|c|c|c|c|}
\hline \multirow{2}{*}{ Genotype } & \multicolumn{7}{|c|}{ 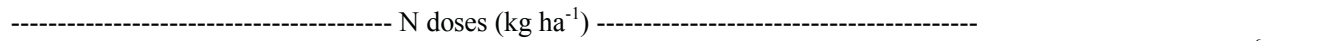 } \\
\hline & 0 & 20 & 40 & 60 & 80 & tvicant & $20(70)$ \\
\hline \multicolumn{7}{|c|}{$\mathrm{pH}$} & \multirow[t]{3}{*}{36,90} \\
\hline ADR 300 & $3.49 \mathrm{a}$ & $3.50 \mathrm{a}$ & $3.37 \mathrm{a}$ & $3.44 \mathrm{a}$ & $3.44 \mathrm{a}$ & 3.44 & \\
\hline \multirow[t]{2}{*}{${ }^{1}$ ADR 7010} & $3.68 \mathrm{a}$ & $3.35 \mathrm{a}$ & $3.29 \mathrm{a}$ & $2.98 \mathrm{~b}$ & $3.03 \mathrm{~b}$ & 3.29 & \\
\hline & & --------- & $3(\mathrm{dag} k$ & ------ & 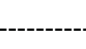 & & \multirow[t]{3}{*}{23.93} \\
\hline${ }^{2}$ ADR 300 & $0.61 \mathrm{~b}$ & $0.94 b$ & $1.19 \mathrm{a}$ & $1.23 \mathrm{a}$ & $1.19 \mathrm{a}$ & 1.19 & \\
\hline \multirow[t]{2}{*}{${ }^{3} \mathrm{ADR} 7010$} & $1.96 \mathrm{a}$ & $1.6 \mathrm{a}$ & $1.30 \mathrm{a}$ & $1.13 \mathrm{a}$ & $1.44 \mathrm{a}$ & 1.44 & \\
\hline & & ------ & dag $\mathrm{kg}^{-1}$ & -1--- & & & \multirow[t]{3}{*}{15.43} \\
\hline${ }^{4} \mathrm{ADR} 300$ & $5.69 \mathrm{a}$ & $4.47 b$ & $4.09 \mathrm{~b}$ & $7.81 \mathrm{~b}$ & $7.90 \mathrm{~b}$ & 5.69 & \\
\hline \multirow[t]{2}{*}{ ADR7010 } & $6.02 \mathrm{a}$ & $9.62 \mathrm{a}$ & $8.83 a$ & $10.46 \mathrm{a}$ & $9.60 \mathrm{a}$ & 9.6 & \\
\hline & & -------' & dag $\mathrm{kg}^{-1}$ & ----- & ------ & & \multirow[t]{3}{*}{25.95} \\
\hline${ }^{5} \mathrm{ADR} 300$ & $0.12 b$ & $0.16 \mathrm{a}$ & $0.32 \mathrm{a}$ & $0.52 \mathrm{a}$ & $0.30 \mathrm{a}$ & 0.3 & \\
\hline \multirow[t]{2}{*}{ ADR7010 } & $0.55 \mathrm{a}$ & $0.26 \mathrm{a}$ & $0.31 \mathrm{a}$ & $0.34 \mathrm{a}$ & $0.28 \mathrm{a}$ & 0.31 & \\
\hline & & & dag $\mathrm{kg}^{-1}$ & -1--1 & ------ & & \multirow[t]{3}{*}{15.43} \\
\hline ADR 300 & 0.01 & 0.01 & 0.01 & 0.01 & 0.01 & 0.01 & \\
\hline ADR7010 & 0.01 & 0.01 & 0.01 & 0.01 & 0.01 & 0.01 & \\
\hline
\end{tabular}

Means followed by same letter in column do not differ by $\mathrm{F}$ test $(\alpha=0.05)$; $\mathrm{N}-\mathrm{NH}_{3}-$ ammonia nitrogen as a percentage of total nitrogen, LA - lactic acid, AA - acetic acid, BA - butyric acid;

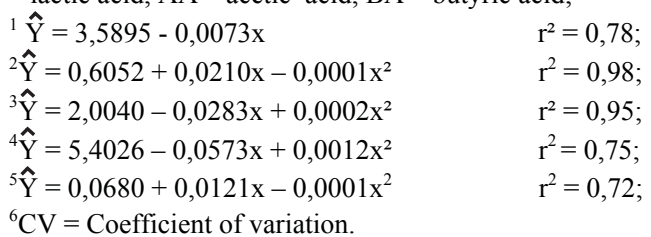

of proteolytic microorganisms (enterobacteria and bacteria from the Clostridium family).

There was no effect of any source of variation $(\mathrm{P}>0.05)$ for the values of butyric acid (BA) (Table 4). The lower values observed in this study (around $0.01 \mathrm{dag} \mathrm{kg}^{-1} \mathrm{DM}$ ) can be explained by the rapid decrease in $\mathrm{pH}$, probably due to the development of LA producing bacteria (LAB).

Table 5 shows that there was an interaction $(\mathrm{P}<0.05)$ between $\mathrm{N}$ doses and the genotypes for the dry matter recovery (DMR). The DMR decreased $(\mathrm{P}<0.05)$ linearly with the increasing in the dosages of nitrogen only for the hybrid ADR7010, the same is not true for the hybrid ADR300. It was observed that the variety ADR300 showed, on average, superiority in the DMR of approximately $14.8 \mathrm{dag} \mathrm{kg}^{-1}$ compared to the hybrid ADR7010.

In the highest doses of fertilizer hybrid ADR7010 showed lower DMR 69.19 and 68.98 for N doses of 60 and $80 \mathrm{~kg} \mathrm{ha}^{-1}$, respectively. This increased loss can be explained by higher losses gases (Table 5) and was also observed when the genotype was subjected to the highest $\mathrm{N}$ doses. This lower DMR can be the result of undesirable fermentations, especially yeast, since this hybrid showed high concentrations of soluble carbohydrates (Table 1), which possibly allowed a reduction in $\mathrm{pH}$ values close to 3.0 (PAIVA et al. 2011). In this $\mathrm{pH}$ range yeasts have greater development in detriment to other microbial groups, resulting in production of ethanol and consequently increasing the losses in the silage.

Concerning the losses by gas, it is possible to say that there was interaction $(\mathrm{P}<0.05)$ between nitrogen doses and the genotypes. It is observed that the hybrid ADR7010, when subjected to dosages of 60 and $80 \mathrm{~kg} \mathrm{ha}^{-1}$ of $\mathrm{N}$, presented higher losses when compared to others. Losses by gas in the hybrid may have been influenced by high concentrations of soluble carbohydrates, which favored a significant drop in $\mathrm{pH}$, lower than the optimum value, stimulating secondary fermentation. Concerning the losses by effluent, it was observed no effect of any source of variation $(\mathrm{P}>0.05)$. This can be explained due to the same doses of DM.

\section{CONCLUSION}

Spite of the increase in crude protein and decreased neutral detergent fiber content, it is 
Table 5 - Average values of dry matter recovery (DMR), losses by gas (G), losses by effluent (E) of two pearl millet genotypes silages under nitrogen $(\mathrm{N})$ fertilization.

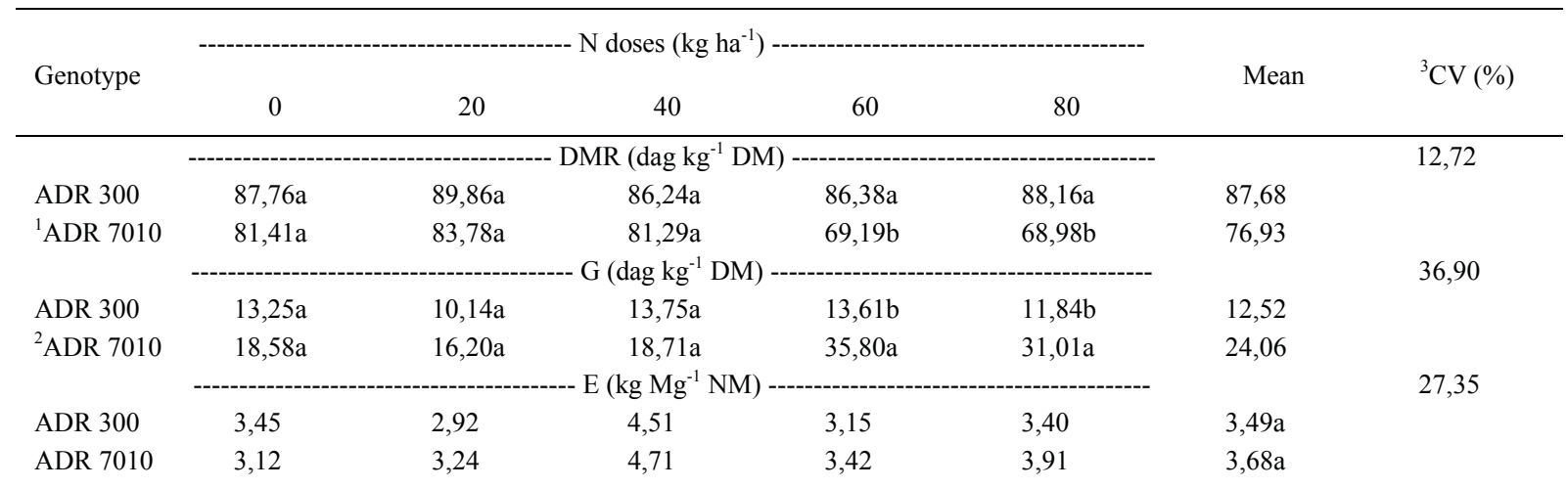

Means followed by same letter in column do not differ by $\mathrm{F}$ test $(\alpha=0.05)$;

$\begin{array}{ll}{ }^{1} \hat{Y}=88,8302-0,2723 x & r^{2}=0,74 \\ { }^{2} \hat{Y}=11,17+0,2723 x & r^{2}=0,64 \\ { }^{3} \mathrm{CV}-\text { Coefficient of variation. } & \end{array}$

observed that the nitrogen fertilization does not favor fermentation and increases the losses of dry matter of hybrid ADR7010. The genotypes under study, when ensiled, result in well-fermented silage with chemical composition, which indicates an adequate nutritional value, providing a feeding alternative to the use as roughage supplementation in semiarid regions.

\section{REFERENCE}

AMARAL, P.N.C. et al. Qualidade e valor nutritivo da silagem de três cultivares de milheto. Ciência e Agrotecnologia, v.32, n.2, p.611-617, 2008. Available from: <http://www.scielo.br/pdf/ cagro/v32n2/41.pdf $>$. Accessed: Nov. 15, 2011.

BOLSEN, K.K. et al. Effect of silage additives on the microbial succession and fermentation process of alfalfa and corn silages. Journal of Dairy Science, v.75, n.11, p.3066-3083, 1992.

DERIAZ, R.E. Routine analysis of carbohydrate and lignin in herbage. Journal of Science Food and Agriculture, v.12, p.150$160,1961$.

DIAS, P.F. et al. Produção e valor nutritivo de gramíneas forrageiras tropicais, avaliadas no período das águas, sob diferentes doses de nitrogênio. Ciência e Agrotecnologia, v.24, n.1, p.260-271, 2000. Available from: <http://www.trc.zootechnie.fr/node/5136>. Accessed: Jul. 25, 2012.

GUIMARÃES JR. et al. Matéria seca, proteína bruta, nitrogênio amoniacal e $\mathrm{pH}$ das silagens de três genótipos de milheto [Pennisetum glaucum (1). R. Br.] em diferentes períodos de fermentação. Revista Brasileira de Milho e Sorgo, v.4, n.2, p.251-258, 2005. Available from: <http:// rbms.cnpms.embrapa.br/index.php/ojs/article/view/145/145>. Accessed: Sept. 14, 2012.
GUIMARÃES JR. et al. Cinética de fermentação ruminal de silagens de milheto. Arquivo Brasileiro de Medicina Veterinária e Zootecnia, v.60, n.5, p.1174-1180, 2008. Available from: <http://www.scielo.br/pdf/abmvz/v60n5/20.pdf $>$. Accessed: May. 14, 2012.

GUIMARÃES JR. et al. Degradabilidade in situ de silagens de milheto em ovinos. Ciência Animal Brasileira, v.11, n.2, p.334343, 2010. Available from: <http://www.revistas.ufg.br/index. php/vet/article/view/7053/6837>. Accessed: May. 12, 2012. doi 10.526/cab.v11i2.7053.

KUNG Jr.; RANJIT, N.K. The effect of Lactobacillus buchneri and other additives on the fermentation and aerobic stability of barley silage. Journal of Dairy Science, v.84, p.1149-1155, 2001. Available from: <http://scielo.isciii.es/scielo.php?script=sci_nlink s\&ref=636818\&pid=S00040592201100020000900005\&lng=es $>$. Accessed: Jan. 10, 2012.

LOURES, D.R.S. et al. Características do efluente e composição químico-bromatológica da silagem de capim-elefante sob diferentes níveis de compactação. Revista Brasileira de Zootecnia. v.32, n.6, p.1851-1858, 2003. Available from: <http://www.scielo.br/ pdf/rbz/v32n6s2/20955.pdf>. Accessed: Sept. 12, 2011.

McDONALD, P. et al. The biochemistry of silage. 2.ed. Merlow: Chalcomb Publications, 1991. 340p.

MERTENS, D.R. Gravimetric determination of amylase teated neutral detergent fiber in feeds with refluxing in beaker or crucibles: collaborative study. Journal of AOAC International, v.85, p.1217-1240, 2002. Available from: <http://www.ingentaconnect. com/content/aoac/jaoac/2002/00000085/00000006/art00003>. Accessed: May. 23, 2012.

NEUMANN, M. et al. Efeito do tamanho de partícula e da altura de colheita das plantas de milho (Zea mays L.) sobre as perdas durante o processo fermentativo e o período de utilização das silagens. Revista Brasileira de Zootecnia, v.36, n.5, p.1395- 
1405, 2007. Available from: <http://www.scielo.br/pdf/rbz/ v36n5/24.pdf>. Accessed: Jun. 18, 2012.

PAIVA, G.N. et al. Perdas na ensilagem de cinco cultivares de sorgo. In: SIMPÓSIO INTERNACIONAL SOBRE CAPRINOS E OVINOS DE CORTE, 2010, João Pessoa, PB. Anais... João Pessoa: SINCORTE. 2011. CD ROM.

SILVA, D.J.; QUEIROZ, A.C. Análises de alimentos (métodos químicos e biológicos). 3.ed. Viçosa: UFV, 2002. 235p.
SNIFFEN, C.J. et al. A net carbohydrate and protein system for evaluating cattle diets: carbohydrate and protein availability. Journal of Animal Science, v.70, n.12, p.3562-3577, 1992.

UNIVERSIDADE FEDERAL DE VIÇOSA (UFV). Sistema de análises estatísticas e genéticas - SAEG. (versão 9.0). Viçosa, 2000. 138p. (Manual do usuário).

ZANINE, A.M. et al. Evaluation of elephant grass silage with the addition of cassava scrapings. Revista Brasileira de Zootecnia, v.39, n.12, p.2611-2616, 2010. Available from: <http://www.scielo. br/pdf/rbz/v39n12/a08v39n12.pdf>. Accessed: May. 27, 2011. 